\title{
British Material Diplomacy in Precolonial Uganda: The Gift Exchanges of John Hanning Speke, 186o-1863
}

\author{
Alison Bennett | ORCID: 0000-0002-8525-5322 \\ Paul Mellon Centre, London, United Kingdom \\ alison.bennett.14@ucl.ac.uk
}

Received: 11 October 202O; revised: 10 December 202O; accepted: 19 January 2021

\section{Summary}

In recent decades the interdisciplinary study of elite gift exchange in various geographical and temporal contexts has transformed historians' understanding of colonial diplomacy. By combining analysis of textual, visual and material sources with theoretical approaches to material culture and gift exchange from anthropology, scholars have increasingly come to examine colonial diplomacy not only through the high-politics and text-based operations of bureaucrats in imperial metropoles, but also as a material and cultural project operating through the local and personal. This essay uses the published account of John Hanning Speke (1863) and his descriptions of 'gift exchanges' in present-day Uganda to understand the materiality of early British diplomacy there. As Speke was the first Briton to reach Uganda, it examines how gift exchanges impacted the logistics and outcomes of his visit. Re-examining his text this way reveals the importance of material knowledge, performance and exchange in early cross-cultural encounters in the region.

\section{Keywords}

diplomacy - imperialism - Uganda - Africa - gift-giving - material culture

\section{Introduction}

In 186o the British explorers, John Hanning Speke and James Augustus Grant, arrived on the shores of Zanzibar to embark on a journey into the interior of 
eastern Africa. ${ }^{1}$ Funded by the Royal Geographical Society, the official aim of their trip was to confirm the source of the White Nile and make other scientific recordings. Beginning in Zanzibar, they planned to travel westwards, circumnavigating Lake Victoria towards the kingdoms of Buganda and Bunyoro in present-day Uganda before locating the Nile's exit to Egypt. ${ }^{2}$ Speke had a second, unofficial aim, however: to scope out a British trade route between Uganda and Egypt and secure trading privileges with local leaders. The events of this trip would lay the foundations for Britain's subsequent imperial encroachment of Uganda which lasted until 1962. Theirs was a route already travelled by African and, more recently, Arab traders. ${ }^{3}$ But as newcomers, Speke and Grant had to travel in stages, slowly forging relations and winning the favour of rulers of the territories along their route. One way which they sought to perform that diplomacy was through the exchange of gifts. As this essay demonstrates, the act of gifting provided an essential way of mediating cross-cultural relations with local leaders in the early years of British contact. ${ }^{4}$

While we can partly infer the nature of these encounters from Speke's publication, David Finkelstein urges readers to consider that Journal of the Discovery of the Source the Nile (1863) was edited by a ghost-writer. ${ }^{5}$ Any analysis must acknowledge its narrative as a blend of reality and discursive colonial representation. ${ }^{6}$ Yet despite amendments, gift exchanges still occupied an important position within the book and remained a consistent social practice throughout the narrative, suggesting that both author and publisher felt they were critical to the expedition and its telling. Moreover, despite being edited in Speke's favour, the resulting narrative still suggests that these encounters were marked by compromise and accommodation, and conflict and instability. As this essay demonstrates, the response and satisfaction of local elites to gift exchanges often determined the physical movements of Speke and Grant, who were reliant on these figures for protection, access to the spaces which they governed and treaty making. Studying gift exchanges offers a critical way of foregrounding indigenous elites in the history of early colonial diplomacy in eastern Africa and also highlights that it was often they who determined the parameters of that diplomacy and interaction.

1 Bridges 1970.

2 Speke $1863,32$.

3 Rockel 2006.

4 For similar works on other regions, see Eaton 2004; Biedermann, Gerritson and Riello 2018; Um 2018.

5 Speke 1863 .

6 For another critical reading that also embraces a material focus, see Youngs 1994. 
The ideas that 1) gift-giving can be found in both 'Western' and 'non-Western' societies, 2) objects are bound up in social as much as economic relations and 3) a gift economy can occur alongside a market economy were first posited by the anthropologists Bronislaw Malinowski and Marcel Mauss in the 1920s. ${ }^{7}$ Their postulations were later developed by scholars such as Christopher A. Gregory, Annette B. Weiner, Arjun Appadurai and Igor Kopytoff, who have all shown that commodities do not always have the same regimes of value, meaning or use throughout their lifespan. ${ }^{8}$ This concept offers a useful framework for understanding the complexities of the objects deployed by Speke as they moved in and out of different geographical, economic, social and political contexts as both commodities and gifts.

The appendix to Journal of the Discovery of the Source of the Nile lists the 'property' (also described as 'African money') that Speke used on the expedition. ${ }^{9}$ This property consisted largely of imported objects purchased from merchants in Zanzibar, and included different varieties of coloured beads, merekani cloth (unbleached American cotton), Omani joho red blanketing, Indian textiles (chintz and gold embroidered Surati silk), kizibao waistcoats, fez hats, sahari turban cloths, firearms and American brass and copper wire. Analysts of global trade and consumption in eastern Africa have produced rich insights into the economic relations surrounding the exchange and demand of these items, insights which have thankfully become increasingly inclusive of local agencies. ${ }^{10}$ As Karin Pallaver writes, beads, for example, were an important form of currency for paying porters and taxes (hongo) along the trade road in present-day Tanzania and Kenya. ${ }^{11}$ Merekani cloth was also used in this way. ${ }^{12}$ Speke's account confirms that these items played pivotal roles as currency commodities. But they also served a range of other political and social purposes which have been overshadowed by the preponderant historiographical focus on commodity exchange. Less attention has been paid to their use as elite gifts, for example, and their subsequent contributions to cross-cultural diplomatic exchange.

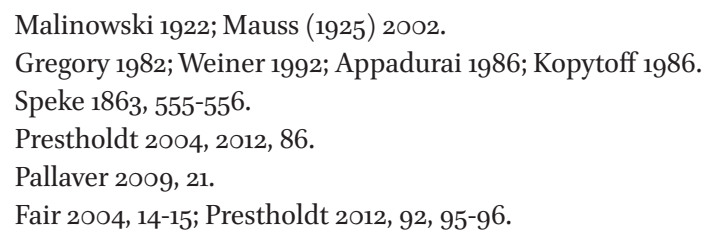


Speke's own descriptive classification of an object as either a gift or currency commodity is particularly interesting because it partly depended on how he perceived the receiver. His evaluation of different individuals and groups was often underpinned by contemporary concepts of race, class and tradition..$^{13}$ Early European visitors to the interior of eastern Africa were intent on finding familiar centres and symbols of power and sovereignty and were fixated on engaging with those individuals who they identified as 'kings'. As Richard Reid notes, for Speke and those who later followed him, 'it was this political form which was the mark of relative civilization, and with which Europeans could most readily empathize and ultimately establish functioning relations.' ${ }^{14}$ Speke believed that he found markers in places such as Karagwe and Buganda and in the figures of 'Kings' Rumanika and Mutesa. For example, at Mutesa's court in Buganda, he described the King's 'insignia', 'cognizance', and 'courtiers' as being 'dressed in the most scrupulously neat fashions.' ${ }^{15}$ The supposedly natural superiority of Mutesa's (and Buganda's) 'barbaric civilization' were due, Speke proposed, to an ancient Caucasoid and Hamitic lineage. ${ }^{16}$ In making this connection, Speke justified his interactions with the Ganda elite by positioning them on a hierarchy above many of their fellow East Africans, while simultaneously positioning them below the European 'race'.

At the same time, Speke also created an imagined regal image for himself. Describing his first approach to Mutesa's palace, Speke explained that he gave his men fez caps and red cloths to make them look like a guard of honour and declared himself to be 'a foreign prince.'17 A key theme running throughout Speke's descriptions of his encounters with the Ugandan Kings is his active use of objects to project himself as a prince rather than a trader: somebody who gifted objects rather than traded them (despite the end goal of these interactions being to secure future trade privileges). ${ }^{18}$ To distinguish himself from the Arab merchants when in attendance of the Kings, he used an umbrella and sat on his own iron stool, seating being 'exclusively the attribute of the king' in Uganda. ${ }^{19}$

For individuals with whom he wished to develop lasting trade and diplomatic relations, such as Mutesa, Speke described his exchanges as 'gifts'. Yet in other regions such as Buzinza, where he designated Ruhe and Lumeresi

\footnotetext{
13 Ranger 1983; Cannadine 2001.

14 Reid 2017, 18.

15 Reid 2017, 281, 271, 296, 284.

16 Sanders $1969,528$.

17 Speke 1863, 274, 276.

18 Speke 1863, 282.

19 Speke 1863, 205, 283.
} 
as 'petty chiefs', or Ngambezi where he depicted the leader as a 'proprietor', he described his material transfers largely as 'taxation' or 'tribute' for passing through the land, 'extortion', and even 'plunder' — in an ironic reversal of later British military incursions. ${ }^{20}$ Speke's classifications of his material exchanges are thus significant for they show that objects not only served important social, political and economic roles in different contexts. They also helped to crystallise in material terms how he understood - or wanted to project - the status and hierarchy of the eastern Africans with whom he was engaging, and himself.

Studying the minutiae of Speke's gift exchanges reveals information about the agency and power of local elites in diplomatic processes. For the purpose of this essay, the author will zoom in on some of Speke's descriptions of his exchanges with Mutesa as examples. On arrival at the palace, Speke's first act was to present his gifts, but his description of the lead-up to this event outlines a fascinating contest for power, with the balance falling back and forth between the two parties. The account begins with an indignant description of Speke being forced to wait to see the King and then reside in a hut usually offered to Arab merchants. ${ }^{21}$ When finally summoned by Mutesa, Speke and his men participated in a 'procession', carrying the Union Jack and presents alongside Mutesa's pages and guards of honour. ${ }^{22}$ Despite the initial fanfare of this entrance, Speke was soon positioned behind other East African envoys and directed to sit on the ground in the sun. In protest, Speke left the palace grounds, an act previously unheard of by other envoys. But he soon returned, albeit with his umbrella and iron chair to emphasise his social position. The initial delivery of Speke's gifts thus played an important role in the dynamics of power between the two parties and set the tone for the next stage of the encounter when the pair came face to face.

At this point, gifts and material culture served critical communicative functions. Describing this first encounter with Mutesa, Speke remarked:

I now longed to open conversation, but knew not the language, and no one near me dared speak ... so the king and myself sat staring at one

\footnotetext{
20 Speke 1863, 197, 168, 258-620, 209.

21 Speke 1863, 276.

22 Speke 1863, 281.
} 
another for full an hour - I mute, but he ... requiring to see my hat lifted, the umbrella shut and opened, and the guards face about and show off their red cloaks — for such wonders had never been seen in Uganda. ${ }^{23}$

Here, Speke's narrative clearly takes a condescending tone as it describes Mutesa's response of awe to his material belongings. Yet it also suggests that objects took on communicative roles when shared linguistics were manifestly lacking. Moreover, it highlights the power of Mutesa's presence in this scene whereby Speke felt unable to approach him and was forced to sit in silence.

After some time had passed, Mutesa invited Speke to a series of private huts where the first gift exchange and, simultaneously, first form of direct contact between the pair took place:

Taking a gold ring from off my finger, and presenting it to him, I said, 'This is a small token of friendship; if you will inspect it, it is made after the fashion of a dog-collar, and, being the king of metals, gold, is in every respect appropriate to your illustrious race. ${ }^{24}$

The description of this scene is deeply loaded and requires careful unpacking. The first striking element is the object itself: a gold ring. Gold was a symbol of precolonial wealth, status and leadership across many parts of Africa, though in Uganda it was not a natural resource and was less freely available. ${ }^{25}$ It was also an important African trade good and created great wealth for many African leaders and traders. By the 19th century, however, British colonisation of the British Gold Coast Colony and South Africa had increased commodification of gold into manufactured luxury consumer items. Thus, while stating that 'gold, is in every respect appropriate to your illustrious race', the gift of this gold ring replicated the unequal flow of African resources and British goods through imperialism.

Next, there is the giving of the ring itself. A rich body of literature is devoted to the study of European rings and their role in maintaining relationships and defining notions of power and identity. ${ }^{26}$ In this affective encounter, the gifted object is transferred from Speke's body to Mutesa's, adding intimate and haptic dimensions to the materiality of the diplomatic scene, an aspect of diplomatic encounters often unrecorded in official colonial documentation.

\footnotetext{
23 Speke $1863,285$.

24 Speke $1863,287$.

25 Fagg 1974.

26 Church 2017.
} 
Bernard S. Cohn has observed that in precolonial and colonial India, the gift of clothing between British envoys and Indian princes incorporated recipients 'into the body of the donor'.27 Here, Speke seems to be forging a similarly personal connection — or 'friendship' as he described it — through the giving of his ring. The implied sarcasm in his referring to the ring as a 'dog-collar' before handing it to Mutesa undercuts this gesture and was perhaps written to imply Speke's intellectual superiority over the Ugandan King to readers.

Though claiming to seek only friendship, the return gift which Speke was hoping for came in Mutesa's supposed reply: 'If friendship is your desire, what would you say if I showed you a road by which you might reach your home in one month?', highlighting how Speke interpreted gift exchange as a precursor to political negotiation. ${ }^{28}$ But a negotiation this was, one which occurred over several months and involved multiple acts of gift-giving and relationship building on Speke's part. Mutesa's power over Speke during these months is revealed throughout the subsequent text, and particularly in the following remark: 'Till now, owing to the strict laws of the country, I had not been able to call upon anybody but the king himself. I had not been able to send presents or bribes to anyone ... neither was anybody permitted to sell me provisions. ${ }^{29}$

A note in Grant's sketchbooks reveals that he and Speke used gifts of images and objects as prompts to finally ask Mutesa for permission to leave the court and proceed on their journey with the King's blessing and protection, to which Mutesa eventually agreed. ${ }^{30}$

\section{Conclusion}

This short example, though clearly not representing the full range of complex exchanges in which Speke engaged during his time in eastern Africa, still illustrates the dynamic, symbolic and physical labour of material objects during this early period of colonial encounter. It adds support to a broader field of historical examinations which draw on approaches from sociocultural anthropology to emphasise the importance of gift exchange in political relations, particularly in colonial settings. Like many other studies, it shows the fluidity of such objects which could be designated as both elite gifts and currency commodities. Yet Speke's text also demonstrates how such designations were often specifically directed by British actors' perceptions of race and class in the

\footnotetext{
27 Cohn 1983, 168.

28 Speke $1863,287$.

29 Speke $1863,294$.

3o $\quad$ MS17919 n.d., 3 .
} 
context of this time and place. Concurrently, examining the cross-cultural gift exchanges between Speke, Mutesa and other eastern African elites in the 186os enriches the arguments of scholars such as Linda Colley, Frederick Cooper and Jeremy Prestholdt about the fragility and ambiguity of cross-cultural relations at this time. Studies of eastern Africa from the later 19th century onwards often emphasise the overwhelming power of colonial authorities who were, by that point, heavily supported by their supply of Maxim guns. But in the 186os, despite their self-styled image of superiority, British reliance on the will of East African leaders was carefully garnered through the bestowal of gifts.

\section{Bibliography}

Appadurai, Arjun. 'Commodities and the Politics of Value'. In The Social Life of Things: Commodities in Cultural Perspective, ed. Arjun Appadurai (Cambridge: Cambridge University Press, 1986), 3-63.

Biedermann, Zoltán, Anne Gerritson and Giorgio Riello, eds. Global Gifts: The Material Culture of Diplomacy in Early Modern Eurasia (Cambridge: Cambridge University Press, 2018).

Bridges, Roy C. 'John Hanning Speke: Negotiating a Way to the Nile'. In Africa and Its Explorers: Motives, Methods, and Impact, ed. Robert I. Rotberg (Cambridge: Harvard University Press, 1970).

Cannadine, David. Ornamentalism: How the British Saw Their Empire (London: Allen Lane, 2001).

Church, Rachel. Rings (London: Thames and Hudson, 2017).

Cohn, Bernard S. 'Representing Authority in Victorian India'. In The Invention of Tradition, eds. Eric Hobsbawm and Terence Ranger (Cambridge: Cambridge University Press, 1983).

Eaton, Natasha. 'Between Mimesis and Alterity: Art, Gift, and Diplomacy in Colonial India, 1770-180o'. Comparative Studies in Society and History 46 (2004), 819-820.

Fagg, William. 'Ashanti Gold'. The Connoisseur 185 (743) (1974), 41-48.

Fair, Laura. 'Remaking Fashion in the Paris of the Indian Ocean: Dress, Performance, and the Cultural Construction of a Cosmopolitan Zanzibari Identity'. In Fashioning Africa, ed. Jean Allman (Bloomington: Indiana University Press, 2004), 13-30.

Finkelstein, David. House of Blackwood: Author-Publisher Relations in the Victorian Era (University Park: Penn State Press, 2010).

Gregory, Christopher A. Gifts and Commodities (London: Academic Press, 1982). Kopytoff, Igor. 'The Cultural Biography of Things: Commoditization as Process'. In The Social Life of Things: Commodities in Cultural Perspective, ed. Arjun Appadurai (Cambridge: Cambridge University Press, 1986), 64-91. 
Malinowski, Bronislaw. Argonauts of the Western Pacific (London: George Routledge and Sons, 1922).

Mauss, Marcel. The Gift: The Form and Reason for Exchange in Archaic Societies (London: Routledge, [1925] 2002).

MS17919. J.A. Grant, Nile Sketches. National Library of Scotland, n.d.

Pallaver, Karin. “A Recognized Currency in Beads”: Glass Beads as Money in 19thCentury East Africa: The Central Caravan Road'. In Money in Africa, eds. Catherine Eagleton, Harcourt Fuller and John Perkins (London: British Museum, 2009), 20-29.

Prestholdt, Jeremy. 'On the Global Repercussions of East African Consumerism'. American Historical Review 109 (3) (2004), 755-781. DOI 10.1086/ahr/109.3.755.

Prestholdt, Jeremy. 'Africa and the Global Lives of Things'. In The Oxford Handbook of the History of Consumption, ed. Frank Trentmann (Oxford: Oxford University Press, 2012), 85-110.

Ranger, Terence O. 'The Invention of Tradition in Colonial Africa'. In The Invention of Tradition, eds. E.J. Hobsbawm and T.O Ranger (Cambridge: Cambridge University Press, 1983), 211-262.

Reid, Richard J. A History of Modern Uganda (Cambridge: Cambridge University Press, 2017).

Rockel, S. Carriers of Culture: Labor on the Road in Nineteenth-Century East Africa (Portsmouth, NH: Heinemann, 2006).

Sanders, Edith R. 'The Hamitic Hypothesis: Its Origin and Functions in Time Perspective'. Journal of African History 10 (4) (1969), 521-532.

Speke, John Hanning. Journal of the Discovery of the Source of the Nile (London: William Blackwood, 1863).

Um, Nancy. 'Nested Containers for Maritime Journeys: Tools of Aromatic Diplomacy around the Late Seventeenth- and Early Eighteenth-Century Indian Ocean'. West 86th: A Journal of Decorative Arts, Design History, and Material Culture 25 (2) (2018), 199-223.

Weiner, Annette B. Inalienable Possessions: The Paradox of Keeping-While-Giving (Los Angeles: University of California Press, 1992).

Youngs, Tim. Travellers in Africa: British Travelogues, 1850-1900 (Manchester, UK: Manchester University Press, 1994).

\section{Alison Bennett}

is a Postdoctoral Fellow at the Paul Mellon Centre in London. She completed her PhD in 2018 with the support of an Arts and Humanities Research Council Collaborative Doctoral Award from University College London and the British Museum. Her research examines the histories of British colonialism and imperialism in eastern Africa predominantly through a material and visual lens. 